\title{
Land Use /Land Cover Change Detection Analysis for Eastern Nile Delta Fringes, Egypt
}

\author{
Enass A.Elimy $^{1 *} \quad$ Ahmed A. Hassan ${ }^{2} \quad$ Maha A. Omar $^{1} \quad$ Gamal .Abd EL Nasser ${ }^{1} \quad$ Peter H. Riad ${ }^{2}$ \\ 1.Research Institute for Groundwater. National Water Research Centre, Cairo, Egypt \\ 2.Irrigation and Hydraulics Department, Faculty of Engineering, Ain Shams University, Cairo,Egypt
}

\begin{abstract}
Egypt has turned its attention to develop many new areas for agricultural development, such as the fringes of the Nile Valley, the eastern, western fringes of the Nile Delta, and also to the desert areas. In this research, integration of GIS and remote sensing (RS\&GIS) were used in the South Eastern Nile delta region to follow the change in land use/cover and to assess the change in the agricultural lands in the desert areas. Three satellite images for years 1992, 2002, 2015 were used to produce the land use/cover maps using the maximum likelihood method by selecting five classes for land cover as (Agricultural, water, desert, and urban). The results of the accuracy assessment were evaluated as $85 \%, 86.2 \%$, and $87.5 \%$ for the years 1992,2002 , and 2015 . The change detection maps were produced between (1992-2002), (2002-2015) and (1992-2015). To follow up the increase in reclaimed areas that previously planned for reclamation by the National Water Resources Plans. More change detection statistics were performed. The results showed an increase in the area of agricultural lands within the desert regions, with values that are aligned with the areas proposed in the previous national water plans. The area of reclamation lands of the existing reclamation projects started before 1992 increased by 17527.6 (feddan) from the year 1992 to 2015 compared to 115436 feddan for the reclamation lands planned by the Land master plan from (1992 to 2017) for the same period of years. Finally, we can consider the integration between GIS and remote sensing data as an important and powerful tool for accurately detection land use/land cover changes over the study area. Also, these tools were considered very useful for the planning of sustainable management for water resource plans.

Keywords: Geographical Information Systems (GIS), Remote Sensing (RS), Land-use/ cover, change detection, the South Eastern Nile delta region.
\end{abstract}

DOI: $10.7176 / \mathrm{JEES} / 10-10-07$

Publication date:October $31^{\text {st }} 2020$

\section{1- Introduction}

The continuous growth of population increases dramatically in Egypt, especially in the last century. Most of this increase concentrated in the Nile Delta Region, Therefore, successive governments have paid great attention to the problem of overpopulation and its extent related to the continuous demand for the agricultural sector with increasing agricultural production. Therefore, Egypt has turned its attention to develop many new areas for development, such as the fringes of the Nile Valley and the eastern and western fringes of the Nile Delta, and also to the desert areas. During 1997 to 2017, increasing in land reclamation areas was 3.4 million faddan for different areas of Egypt (Abdel Salam et al., 2004). These development projects require continuous monitoring to avoid large-scale environmental deterioration (Abu Zeid, 1991) depending on the National Water Plans during the period from 1997 to 2017 demonstrated by the Ministry of Water Resources and Irrigation (MWRI).

In this research, the South Eastern Nile delta region was chosen to follow the change in land use/cover and to assess the change in the agricultural lands in the desert areas located southeast of the Nile Delta fringes. So the changes in the agricultural expansion especially must be quantified and detected to help in the process of sustainable management of water resources. The area of the South-Eastern Nile delta changed drastically in the last 30 years. Since 1980, the area of the South-Eastern Nile delta changed as a result of extensive reclamation of desert areas and relatively large enterprises (large scale projects) cultivated with surface water from the Ismailia Canal. In addition to the private farms surrounding the Ismailia Canal and other areas irrigated conjunctively (Abdel Salam et al., 2004). Many factors have a great effect on the rapid and dynamic change in the study area, such as a) continuous increase of reclamation land by increasing the cultivation areas .b) the changing of irrigation source from groundwater to surface water or conjunctive use. c) The rapid growth of urban areas over the existing cultivation areas. d) Changing the areas of sand dunes and barren desert to urbanization or cultivation areas (Abo El Magd, 2011). Many previous studies have attempted to assess and detect the land use/cover change in different areas in the Eastern Delta region. Abdulaziz A. M. et al., 2009 used a hybrid classification approach to asset and monitor land use/cover changes associated with the agricultural and urban expansion in the Eastern Nile Delta especially in the desert fringes by classifying Landsat images. Three land cover maps were obtained for years 1984, 1990,2003 . These maps are used to create changes detection maps by post-classification and some statistics for the obtained land use maps. The results presented an increase in the agricultural area by $14 \%$ over the study period. Also, the urban areas increased by 21,300 hectares during the period from 1990-2003. Also, Abo EL Magd, 2011 Applied the data of remote sensing through the period (1990-2008) for Eastern Nile Delta Region, the author 
categorized the study area according to land cover and water resources.

Riad, P. et al. (2020), Used different landsat datasets from 1970 to 2018 to study how the urban expansion affects the agricultural area in four cities (Luxor, Cairo in Egypt, and Aqaba and Amman in Jordan). The authors had applied the spectral Angle Mapper and the Maximum Likelihood Algorithm to perform landcover classification and post-classification comparison for change detection. The images were processed by using different ERDAS IMAGINE 2014 tools and open-source approaches implemented in QGIS. Other previous studies have addressed the methodology of monitoring land use map and detect the change between the produced land use maps among these studies El-Kawy et al., 2011, Berberoglu, S., \& Akin, A. 2009, Hegazy, I. R., \& Kaloop, M. R. 2015. The objective of this study is to monitor the rate of increase in the reclamation lands by increasing the agricultural areas as it is considered one of the main factors that have a great effect on the rapid and dynamic change in the study area. Observing and quantifying the changes of the land cover for the classified land use maps between 1992, 2002, and 2015.by integration of remote sensing data and GIS (RS\&GIS) considered important and powerful tools for accurately detection land use/land cover changes over large areas.

\section{2- Materials and Methodology}

\section{2-1 Location of Study Area}

The area presented in this study covers part of the Eastern Nile delta Region located between $31^{\circ} 00^{\prime}$ and $32^{\circ} 00^{\prime}$ E longitude and $30^{\circ} 00^{\prime}$ and $30^{\circ} 31^{\prime} \mathrm{N}$ latitude. The study area is bounded by the Damietta branch to the west, to the East by Suez Canal, to the north by Lake EL Manzala, and to the south by Cairo-Suez desert Road. It occupies part of the flood plain in the North West direction. Another portion of the study area occupies by a high land desert area located north and south Ismailia canal. Where is considered the natural extension of flood plain towards the east Abdulaziz, A. M. (2007) .The study area is characterized by an arid to semi-arid climatic conditions. The climate is dry, hot, and rainless in the summer. But it is mild with some precipitations in the winter with mean, monthly temperature ranges from about $12_{0} \mathrm{c}$ in winter to $27_{\mathrm{o}} \mathrm{c}$ in summer. The Eastern Nile Delta region covered an area of approximately $14,000 \mathrm{~km} 2$, it is characterized by different topographic features. The ground elevations have a gentle slope to the east direction. It is characterized by extensive and rapid development projects since 1980 depending on the conjunctive use of surface water and groundwater Figure 1.

\section{2-2 Datasets}

In this study, three Landsat images are used for the years 1992, 2002, and 2015, Table 1. These images were downloaded and composited together to monitor the change in the special and temporal patterns of the high desert land area located north and south of Ismailia canal Eastern Nile Delta Fringes. The three Landsat images were downloaded from the USGS website https://earthexplorer.usgs.gov/ Landsat data are available at the website for free download. The three images were mostly cloud free. The acquisition date for the used images was selected in the summer period (August and September) to maintain the intensity of crops, where active and green agricultural fields are existing (Ismael, A. M, 2007). This clarity in agricultural lands greatly helps in the classification process between the agriculture class and the bare soil or urban areas. Figure 2. The Landsat images already had a geographic special reference as the Universal Transverse Mercator (UTM) projection system and projection as (zone: $36 \mathrm{~N}$, datum: WGS-84) with cell size $(30 \mathrm{~m} \times 30 \mathrm{~m})$ represents the image spatial resolution.

Table .1 Satellite data sets characterization for the study area

\begin{tabular}{|l|l|l|l|}
\hline Platform(Sensor) & Acquisition Date & Path/Row & No. of bands \\
\hline Landsat 5 TM+ C1 Level-1 & $26 / 09 / 1992$ & $176 / 039$ & 7 \\
\hline Landsat 7 ETM+ C1 Level-1 & $01 / 09 / 2002$ & $176 / 039$ & 7 \\
\hline Landsat 8 OLI/TIRS C1 Level-1 & $14 / 08 / 2015$ & $176 / 039$ & 11 \\
\hline
\end{tabular}




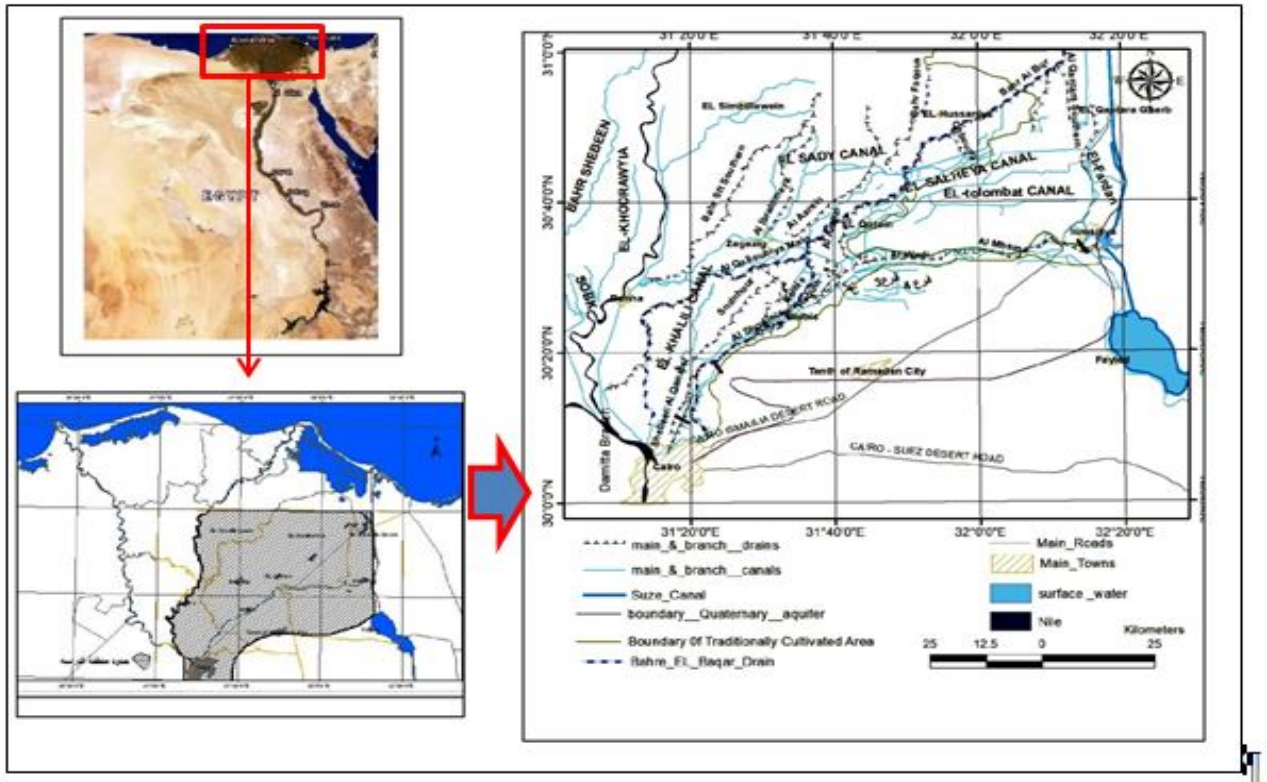

Figure 1. Location map of the study area

In this research different softwares were adopted to complete our classification and change detection analysis required to achieve the objective of the research. Arc GIS version 10.3 was used for pre-processing and for performing the classification processes, Google Earth program for extracted the data corresponding to the ground truth referenced points required for the Accuracy Assessment process. finally Microsoft Excel Worksheet for representing the results in the form of charts and tables also for creating and tabulating the Error matrix to calculate the required values for assessing the accuracy of our classification.
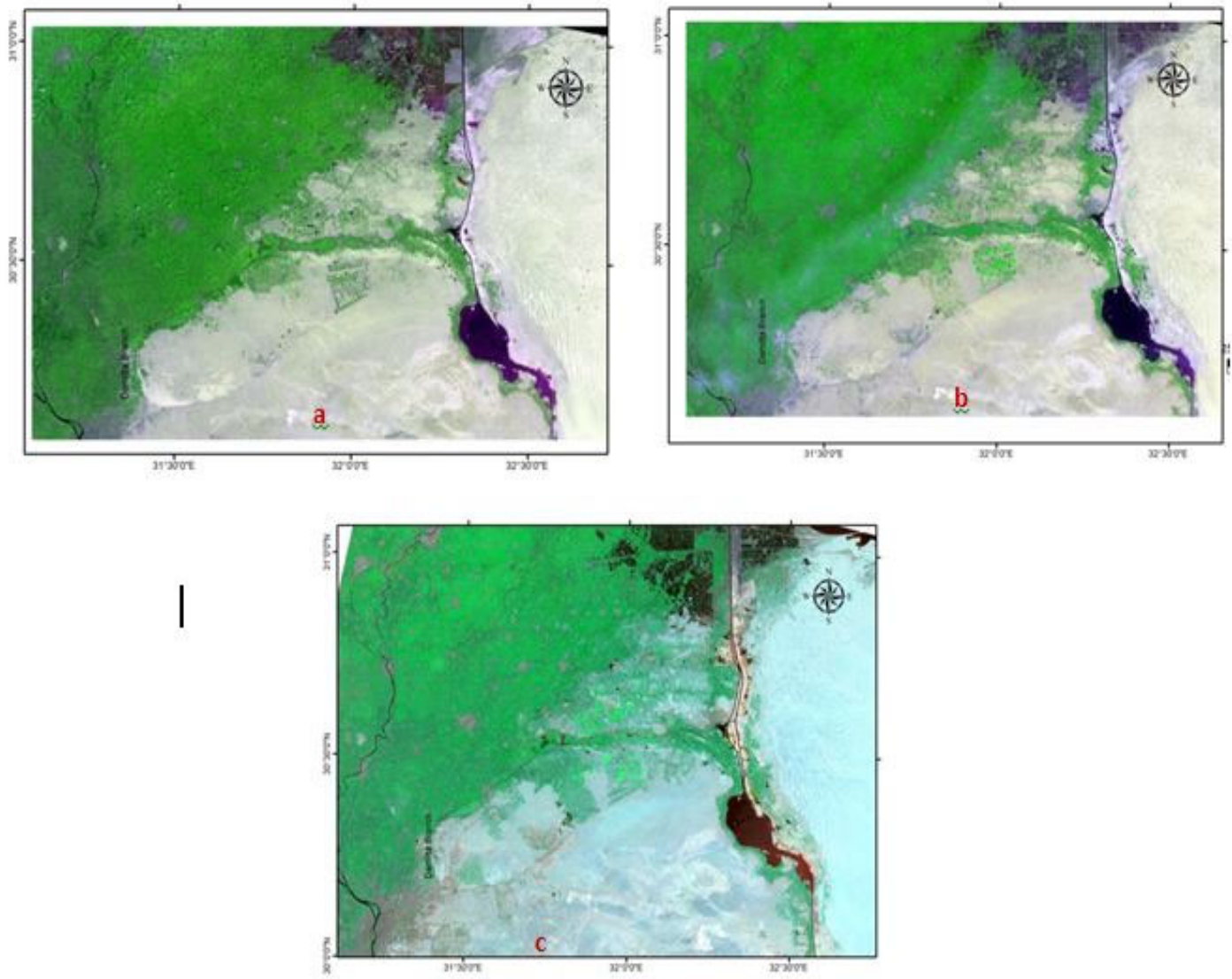

Figure 2. The selected Landsat images with band combinations for the years a) 1992 (RGB 2, 4, 1), b) 2002(RGB 3, 4, 1), and c) 2015 (RGB 6, 3, 2). 


\section{3- Image classification}

This study describes the assessment of land use/land cover classification processes which adopted the pixels classification based method. This method involves multivariable spectral classification. Abburu and Golla (2015) referred to classify satellite image as a combination of the value of image pixel into valid or useful groups. according to Singh, Abhishek, et al. (2020) Image classification is the process of land use detection by the way of labeling each pixel by a class label. Depending on the interconnection between the computer and the analyst during classification. the image classification process contains supervised and unsupervised. With the Spatial Analyst extension in the ArcGIS, there are a group of tools in the Multivariate toolset to achieve supervised and unsupervised classification in the supervised classification previous information about the area under classification is required. (ArcGIS10.3, help).

The maximum likelihood classification tool which works in the same way as the interactive supervised classification method in the ARC GIS program was used to perform the classification. The maximum likelihood rule is the greatest popular supervised classification method used for the satellite images analysis (BOLSTAD and Lillesand, 1991)

Generally, the supervised classification method basically relies on the user's accuracy and experience (Esam et al, 2012). The classification was performed on the three Landsat images using a signature file. Although the spectral analysis shows the clear difference between agricultural lands, whether cultivated or harvested areas and the urban areas, however, the harvested areas, and urban classes are very similar to each other during the classification processes. To avoid this interference during the classification process, the agricultural lands were divided (Due to the difference in color) into two separate classes (cultivated, harvested), but both of them were considered as agricultural lands in the classification accuracy calculations and change detection analysis. So five different classes are chosen and classified according to the existing land features of the study. The classification process produced the five classes as cultivated, harvested, water, desert, and urban areas. Using ARC GIS version 10.3 a maximum likelihood classification tool was used to perform the classification on Landsat (1992, 2002, and 2015 ) to identify the land cover changes in the selected study area.

\section{4- The Classification accuracy Assessment}

Classification accuracy is defined as the measure of proximity of the results of the classification to the true values extracted from the reference maps. Also, the sample number of each class and the quality degree of the reference maps have a great effect on the certainty of the classification (Esam et al, 2012). To perform the accuracy assessment 80 points were chosen to represent the reference points (checkpoints) corresponding to reference maps (Google Earth maps and satellite imagery for the year (1992, 2002, and 2015) these checkpoints were chosen randomly according to the land use classes used for the image classification. 20 points were chosen to represent the classification class as the classification have four classes. The classification and reference data were extracted for the selected eighty checkpoints to perform the interpolation and the analysis of the data to build the error matrix. Excel software was used to build the error matrix and computing the Kappa coefficient for classification. According to Olofsson, Pontus, et al. (2014) the error matrix defined as a quite cross-tabulation of the labels of the classes resulted from the remotely sensed data classification opposed to the sample sites reference data. This matrix organizes the data obtained from the simple random sampling points (reference data) and the corresponding data from the classification. The main objective of the error matrix is to calculate the producer's accuracy, user's accuracy, the total accuracy, the overall accuracy, and finally the Kappa coefficient value to determine the degree of confidence of our classification. In the classification process, the classifier gives some omission errors due to the failure of recognizing some class pixels, the evaluation of these errors is called by the producer's accuracy. But the measure of other errors (commission errors) related to these pixels from other classes that the classifier has recognized to the same class is called the user's accuracy (Ammeish.et al, 2016). The error matrix expresses the degree of accuracy between checkpoints and the value resulting from the classification of the same image. This method is considered one of the essential and popular methods for detecting the overall classification using producer accuracy, user accuracy, and kappa coefficient (Zaidi S.M., et al., 2017).

\section{5- Change detection}

Change detection is a common technique of remote sensing where a comparison between imagery for an area at different times takes place giving the change in the image feature (Esam et al, 2012). Many authors had adopted digital change detection techniques. Various techniques for remotely sensed data and change detection methodologies have been advanced and still newer techniques are arising (Hussain et al., 2013). Ban, Y., \& Yousif, O. (2016) presented various methods for the change detection process for both synthetic aperture radar (SAR) and optical images; they reviewed different conditions of the change detection process as pre-processing of data, generation of change detection, and different change detection algorithms.

This work aimed to detect and calculate the amount of change from different classified land use maps during the period from 1992 to 2015 especially monitoring the change in the agricultural areas by subtracting the classified 
image for years 1922, 2002, 2015 from each other. the main development in the study area associated with the agricultural expansion especially the area of south Eastern Nile Delta located north and south of Ismailia canal, this area had a rapid expansion in the agricultural projects since 1980 to now.

\section{6- Results and Discussion}

The image classification performed for the study area represented a part of the Eastern Nile delta Region, presented three land use /cover maps for three different dates 1992, 2002, and 2015 as shown in Figure 3. Five different classes are chosen and classified according to the existing land features of the study. The classification process produced the five classes (cultivated, harvested, water, desert, and urban areas. Before performing the classification processes each class was sampled by many polygons to create the training sample file in the three satellite images. There was a difficulty to distinguish between some agricultural and urban areas because they have similar infrared spectral colors this was the reason to isolate the class for agricultural into two classes (cultivated \&harvested) to decrease the interference between the areas agricultural and urban areas during the classification. It can be seen that the total classified area was $(8953 \mathrm{~km} 2)(2,130,891$ feddan). The results showed a great difference between the three classified images, especially between the agricultural and desert areas. In 1992 land use map, there was more than 485,928 feddan for desert areas as $22.8 \%$ of the total area. This area was decreased in 2002 and 2015 to 404,094 and 295,045 feddan as 18\% and $13 \%$ respectively. This decrease in the desert land was faced by an increase in the agricultural area in 1992, the agricultural land covered $(1,475,658.6$ feddan) as $69.2 \%$ of the total area. While it covered about (1,658,676.8 feddan) as $77.8 \%$ of the total area in 2015 . It was noticed that the agricultural land has increased from the year 1992 to 2015 by (183,018 feddan) by a percentage as $8.6 \%$ this increase in the agricultural land was subjected to the extensive reclamation projects in the area since 1980 to 2015 related to the management plans and strategies applied to Eastern Nile delta. Also, the results showed that there is an increase in the urban areas during the period between years 1992 to 2002 by $5.4 \%$ but recorded a decrease by a value of 3.4\% from 2002 to 2015 . also, the areas covered with water recorded an increase of $0.5 \%$ from 1992 to 2002 this is maybe due to the construction of new canals in addition to the appearance of some logging areas in lands near the Ismailia canal. While a decrease in these areas is appeared by $1.9 \%$ from 2002 to 2015. All areas and percentage values of classified images are shown in Table 2. 

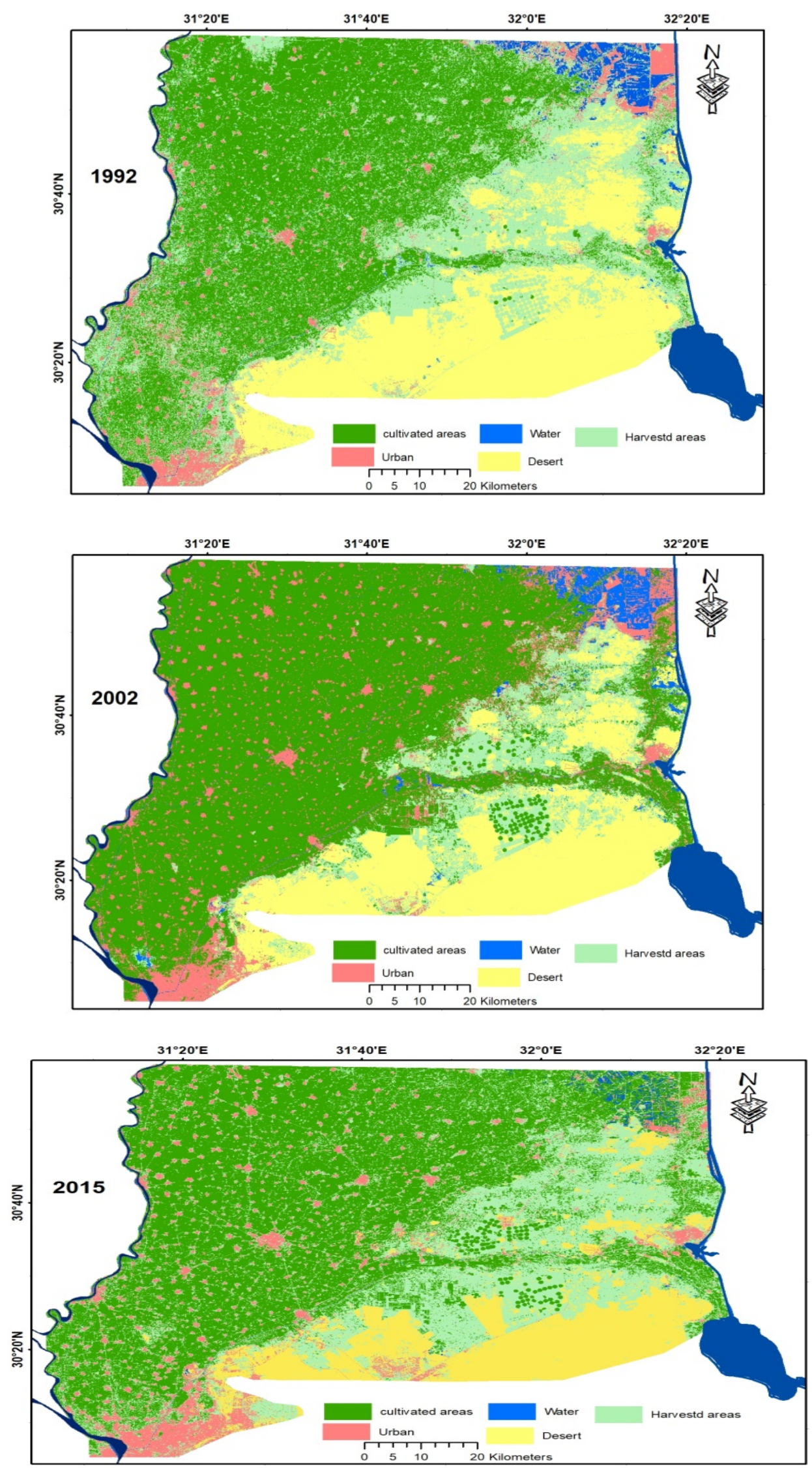

Figure 3. Land use maps produced by the classification processes for the years 1992, 2002, and 2015

Also, the areas covered with water recorded an increase of $0.5 \%$ from 1992 to 2002 this is maybe due to the construction of new canals in addition to the appearance of some logging areas in lands near the Ismailia canal. 
While a decrease is appeared by $1.9 \%$ from 2002 to 2015 . All areas and percentage values of classified images are shown in Table 2 and Figure 4.

Before evaluating the change detection between the satellite images the accuracy of the three land-use maps resulted from the classification should be checked. The accuracy assessment method adopted in this research was the generating of the error matrix by comparing the truth values of sampling points by the classified images for each class type. for each land-use map, an error matrix was produced as shown in Table 3. as (user's and producer's accuracy) for each separate land class, overall accuracy, and overall Kappa ( $\kappa$ ).the results showed that the user's accuracies were $69 \%, 89 \%$, and $67 \%$ for 1992,2002 , and 2015 respectively. While the results presented the value of producer's accuracies as $91 \%, 89 \%$, and $100 \%$ for the same years the overall accuracies evaluated as $85 \%$, $86.2 \%$, and $87.5 \%$ for the same years respectively. Finally, the classification was evaluated for each year by the value of overall Kappa $(\kappa)$ coefficient values as $0.794,0.815$, and 0.832 for 1992, 2002, and 2015 respectively. According to (Borana and Yadav,2017) the degree of agreement depending on the value of overall Kappa ( $\kappa)$ was evaluated as substantial for the year 1992 and Almost Perfect for the years 2002 and 2015.

Table 2. Land use/cover statistics resulted from the classification process

\begin{tabular}{|c|c|c|c|c|c|c|c|c|c|}
\hline & \multicolumn{3}{|c|}{ year 1990} & \multicolumn{3}{|c|}{ year 2002} & \multicolumn{3}{|l|}{ year 2015} \\
\hline class Name & $\begin{array}{l}\text { Area } \\
\left(\mathbf{k m}^{2}\right)\end{array}$ & $\begin{array}{l}\text { Area } \\
\text { ( feddan) }\end{array}$ & $\begin{array}{l}\% \text { of } \\
\text { total } \\
\text { area }\end{array}$ & $\begin{array}{l}\text { Area } \\
\left(\mathbf{k m}^{2}\right)\end{array}$ & $\begin{array}{l}\text { Area } \\
\text { ( feddan) }\end{array}$ & $\begin{array}{l}\% \text { of } \\
\text { total } \\
\text { area }\end{array}$ & Area $\left(\mathrm{km}^{2}\right)$ & $\begin{array}{l}\text { Area } \\
\text { ( feddan) }\end{array}$ & $\begin{array}{l}\% \text { of } \\
\text { total } \\
\text { area }\end{array}$ \\
\hline Agricultural area & 6200.25 & 1475658.6 & 69.25 & 6036.148 & 1436603.2 & 67.42 & 6969.23 & 1658676.8 & 77.83 \\
\hline Urban area & 481.25 & 114536.5 & 5.38 & 943.7412 & 224610.4 & 10.54 & 643.0786 & 153052.7 & 7.182 \\
\hline Desert & 2041.72 & 485928.56 & 22.8 & 1697.876 & 404094.4 & 18.96 & 1239.688 & 295045.85 & 13.84 \\
\hline Water & 230.12 & 54768.006 & 2.57 & 275.4982 & 65568.567 & 3.08 & 101.3318 & 24116.967 & 1.13 \\
\hline Total & 8953.32 & 2130891.6 & 100 & 8953.263 & 2130876.6 & 100 & 8953.329 & 2130892.3 & 100 \\
\hline
\end{tabular}

(*) the two classes (cultivated \& harvested) are merged into one class as agricultural

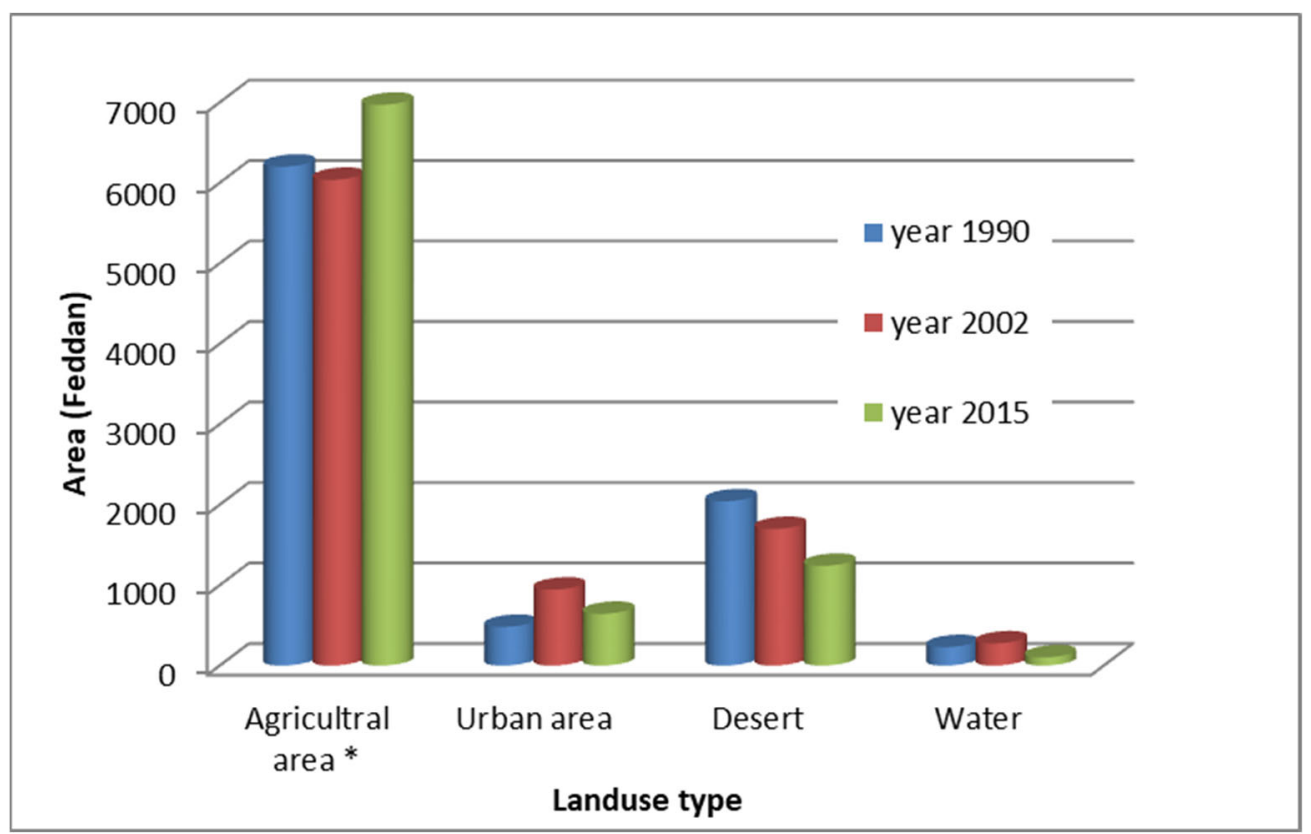

Figure 4. Chart showing Land use/Cover maps for the years 1992, 2002, and 2015. 
Table 3. Classification accuracy statistics and Error matrices for the classified images (1992, 2002, and 2015).

\begin{tabular}{|c|c|c|c|c|c|c|c|}
\hline Year 1992 & Agricultural & urban & desert & water & Total & User's accuracy & $\begin{array}{l}\text { producer's } \\
\text { accuracy }\end{array}$ \\
\hline Agricultural & 20 & 3 & 3 & 3 & 29 & 0.69 & 0.91 \\
\hline urban & 2 & 8 & 0 & 0 & 10 & 0.8 & 0.67 \\
\hline desert & 0 & 1 & 24 & 0 & 25 & 0.96 & 0.89 \\
\hline water & 0 & 0 & 0 & 16 & 16 & 1 & 0.84 \\
\hline Total & 22 & 12 & 27 & 19 & 80 & & \\
\hline $\begin{array}{l}\text { Overall } \\
\text { Accuracy }\end{array}$ & \multicolumn{7}{|l|}{85} \\
\hline Kappa coeff & \multicolumn{7}{|l|}{0.7940} \\
\hline Year 2002 & Agriculture & urban & desert & water & Total & User's accuarcy & $\begin{array}{l}\text { producer's } \\
\text { accuarcy }\end{array}$ \\
\hline Agricultral & 17 & 0 & 1 & 1 & 19 & 0.89 & 0.89 \\
\hline urban & 2 & 13 & 1 & 4 & 20 & 0.65 & 0.87 \\
\hline desert & 0 & 1 & 24 & 0 & 25 & 0.96 & 0.92 \\
\hline water & 0 & 1 & 0 & 15 & 16 & 0.94 & 0.75 \\
\hline Total & 19 & 15 & 26 & 20 & 80 & & \\
\hline $\begin{array}{l}\text { Overall } \\
\text { Accuarcy }\end{array}$ & \multicolumn{7}{|l|}{86.2} \\
\hline Kappa coeff & \multicolumn{7}{|l|}{0.815} \\
\hline Year 2015 & Agricultral & urban & desert & water & Total & User's accuarcy & $\begin{array}{l}\text { producer's } \\
\text { accuarcy }\end{array}$ \\
\hline Agricultral & 20 & 2 & 1 & 7 & 30 & 0.67 & 1.00 \\
\hline urban & 0 & 15 & 0 & 0 & 15 & 1.00 & 0.88 \\
\hline desert & 0 & 0 & 22 & 0 & 22 & 1.00 & 0.96 \\
\hline water & 0 & 0 & 0 & 13 & 13 & 1.00 & 0.65 \\
\hline Total & 20 & 17 & 23 & 20 & 80 & & \\
\hline $\begin{array}{l}\text { Overall } \\
\text { Accuracy }\end{array}$ & \multicolumn{7}{|l|}{87.5} \\
\hline Kappa coeff & \multicolumn{7}{|l|}{0.832} \\
\hline
\end{tabular}

After checking the accuracy of classification the land-use raster datasets were converted into polygon features to extract the areas of each class to a separate shapefile. the study concerned the agricultural expansion with more interest so, In this study, the desert fringes of the Southern Eastern Nile delta region was chosen to evaluate quantitatively the change of the Agricultural development and its relation with the water national plans for desert reclamation in the study area by monitoring and mapping the change in the land cover during the period (1992-2015). The results of the change detection maps as presented in Table 4 and Figure 5 that showed an increase in the agricultural areas accompanied by decreasing in the desert areas during the period 1992-2015. The results showed an increase in the agricultural area by $8.6 \%$, this increase was related to the decrease of the desert area by $8.9 \%$.the results were concentrated on the agricultural class changes by producing the Agricultural area change detection maps for the study area between (1992-2002), (2002-2015) and (1992-2015), respectively

Table 4. The land cover change in feddan between the year 1990 and 2015

\begin{tabular}{|l|l|l|l|l|}
\hline class Name & year 1990 (feddan) & year 2015 (feddan) & total change & \% change \\
\hline Agricultural area & 1475658.554 & 1658676.757 & 183018.203 & 8.588805948 \\
\hline Urban area & 114536.501 & 153052.7003 & 38516.1993 & 1.807515082 \\
\hline Desert & 485928.5647 & 295045.8539 & -190882.711 & -8.95787708 \\
\hline Water & 54768.00642 & 24116.96687 & -30651.0395 & -1.43841338 \\
\hline
\end{tabular}



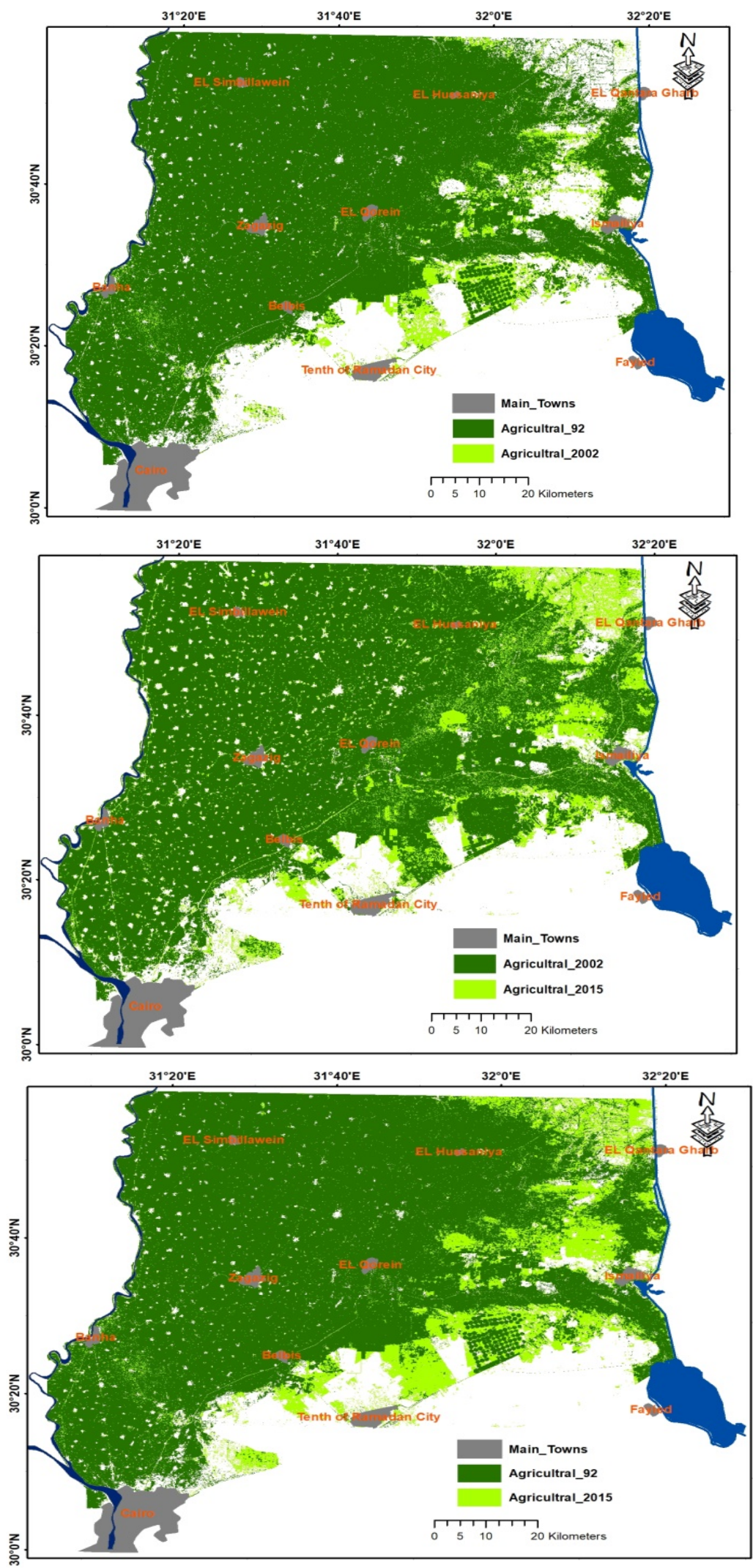

Figure 5. Agricultural area change detection maps for the study area during the period (1992-2015)

To deduce the effect of past national plans for desert reclamation in the desert fringes by monitoring and mapping the agricultural change in the land cover during the period (1992-2015). Many desert reclamation projects have been accelerated at the High land of the desert fringes of the Eastern delta. These high lands include sand dunes and barren desert. The High land was divided into two subareas (A, B) according to the existing large scale 
projects started before 1990. Subarea A includes these regions Shabab, Mulak, Ramsis, Khattara, and Salheya and Land master plan areas B includes Desert Fringes Bilbies, Adleya, Ramsis, Shabab (Youth Province), Manayff, South Cairo -Ismailia Desert Road, Khattara, Salheya North, and Along Husseiniya Canal). the two subareas are bounded to the west by the boundary of traditionally cultivated area and from the north by part of the wetlands and from the east by the Suez canal and the south by the boundary of the Nile Delta quaternary aquifer, Figure 6 and Table 5. The reclaimed desert area located north and south of the Ismailia canal was specified with more change detection data analysis. So the Agricultural land expansion only for this area was extracted and analyzed during (1992-2002), (2002-2015) and (1992-2015) Figure 7. The results indicate an increase in the area of agricultural lands within the desert regions, with values that are aligned with the areas proposed in the previous national plans water .the area of agricultural lands increased by about 8388.5 and 40301.6 feddan during 1992-2002 for Agricultural areas of land use subarea A and B respectively.at the other side these areas increased by about 9139.1 and 75134.4 feddan during 2002-2015 for Agricultural areas of land use subarea A and B respectively. Table 6 presented the amount of change in the agricultural area for the High land including the development areas for land use subarea (A, B) during the period 1992-2015. while Figure 8 illustrated the Graphical representation for the amount of Agricultural area increasing for land use subarea (A, B) during the period 1992-2015.from the results it can be concluded that the agricultural areas of land use subarea (A) have an acceleration rate higher than land use subarea (B).

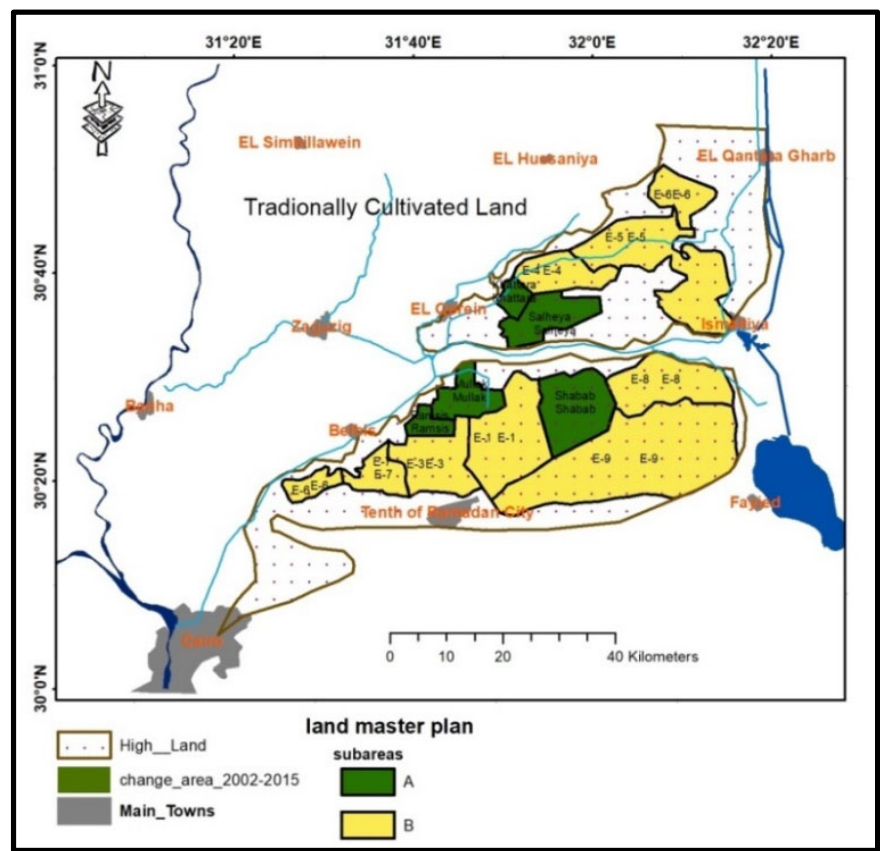

Figure 6. Location of High Land with sub-areas A and B (modified after RIGW/IWACO, 1988)

Table 5. Land Reclamation Areas identified by past national plans for desert reclamation plans till 2017 (modified after RIGW/IWACO, 1988 and MWRI, 2005)

\begin{tabular}{|c|c|c|c|c|c|}
\hline Areas identified by Land Master plan & Subarea & Unit & Till 1990 & Till 2000 & 2017 \\
\hline Desert Fringes Bilbeis & \multirow{9}{*}{$\mathrm{B}$} & E-6 & - & 7000 & \\
\hline Adleya & & E-7 & - & 8000 & \\
\hline Ramsis & & E-3 & - & 19000 & \\
\hline Shabab (Youth Province) & & E-1 & - & 29000 & 17500 \\
\hline Manayff & & E-8 & - & 23000 & 30000 \\
\hline South Cairo -Ismailia Desert Road & & E-9 & - & 62000 & \\
\hline Khattara & & E-4 & - & 16000 & \\
\hline Salheya North & & E-5 & & 88000 & \\
\hline Along Husseiniya Canal & & E-6 & - & 10000 & 16000 \\
\hline \multicolumn{6}{|l|}{ Large scale projects } \\
\hline Shabab & \multirow{5}{*}{ A } & 1 & 20000 & & \\
\hline Mulak & & 2 & 11000 & & \\
\hline Ramsis & & 3 & 9000 & & \\
\hline Khattara & & 4 & 6000 & 16000 & \\
\hline Salheya & & 5 & 14000 & 30000 & \\
\hline
\end{tabular}



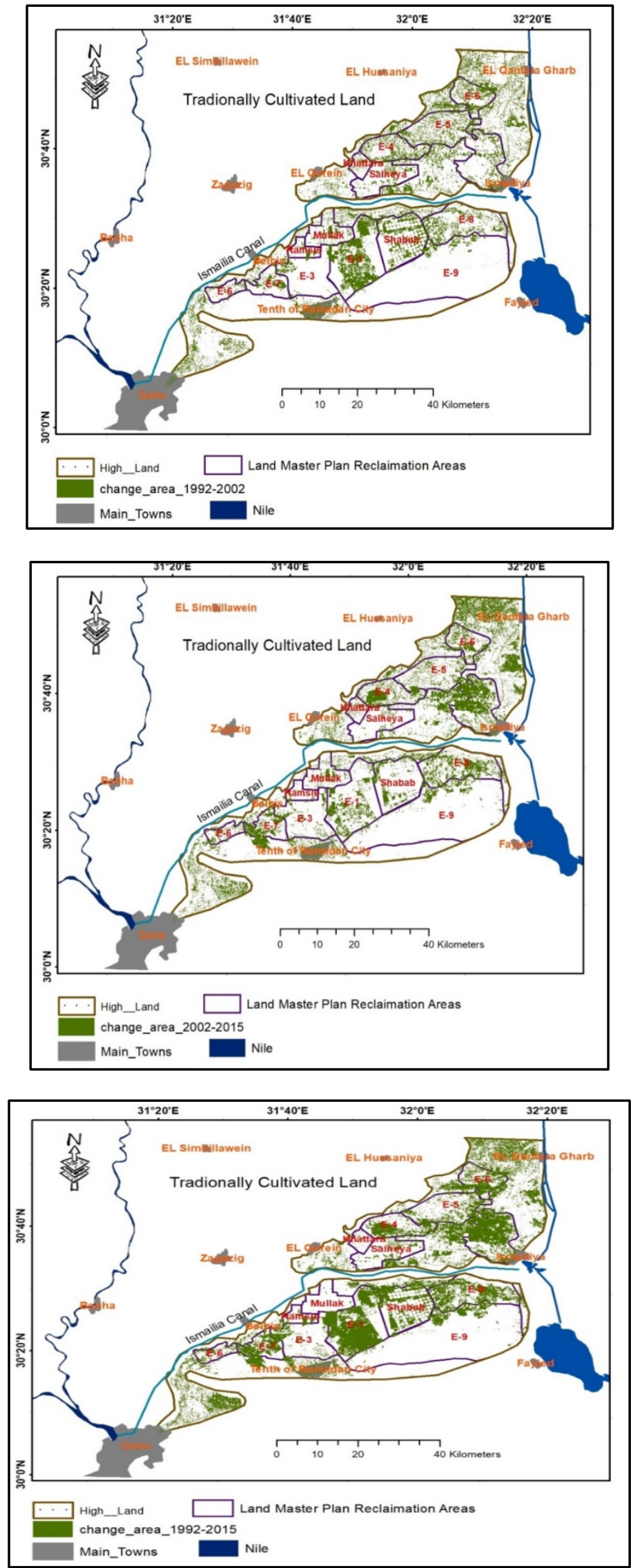

Figure 7. Change detection of Agricultural development in Land master plan areas and the existing large scale projects during the period ((1992-2002), (2002-2015) and (1992-2015), respectively 
Table 6. the amount of change in agricultural area for the High land including the development areas for land use subarea (A, B) during the period 1992-2015.

\begin{tabular}{|c|c|c|c|}
\hline Development Area & 1992 & 2002 & 2015 \\
\hline Landuse & \multicolumn{3}{|l|}{ Area (Feddan) } \\
\hline Shabab & 18080.06458 & 27276.08064 & 31218.46422 \\
\hline Salheya & 18783.02412 & 20861.02139 & 21453.39536 \\
\hline Mulak & 17230.78267 & 14450.99146 & 17541.65029 \\
\hline Ramsis & 3099.225132 & 3975.420321 & 4514.545307 \\
\hline Khattara & 6310.96752 & 5329.029355 & 6303.576616 \\
\hline \multirow[t]{2}{*}{ Total } & \multicolumn{3}{|c|}{ Land use subarea(A) } \\
\hline & 63504.06403 & 71892.54317 & 81031.63179 \\
\hline Ramsis & 1717.089067 & 4058.973756 & 7888.654252 \\
\hline Adleya & 2786.136761 & 4746.144537 & 9232.524601 \\
\hline Desert Fringes Bilbeis & 2421.057779 & 2218.950841 & 2888.642139 \\
\hline Manayff & 12277.78406 & 18176.58612 & 29035.39685 \\
\hline Shabab (Youth Province) & 6413.776242 & 26842.64589 & 38343.69885 \\
\hline $\begin{array}{l}\text { South Cairo -Ismailia Desert } \\
\text { Road }\end{array}$ & 3091.924073 & 6378.191963 & 11600.30073 \\
\hline Khattara & 12922.53204 & 13406.65813 & 21700.49513 \\
\hline Salheya North & 28042.02512 & 34145.77518 & 54071.15862 \\
\hline Along Husseiniya Canal & 7319.611454 & 6803.697231 & 10347.48667 \\
\hline \multirow[t]{2}{*}{ Total } & \multicolumn{3}{|c|}{ Land use subarea(B) } \\
\hline & 76991.9366 & 116777.6236 & 185108.3579 \\
\hline
\end{tabular}

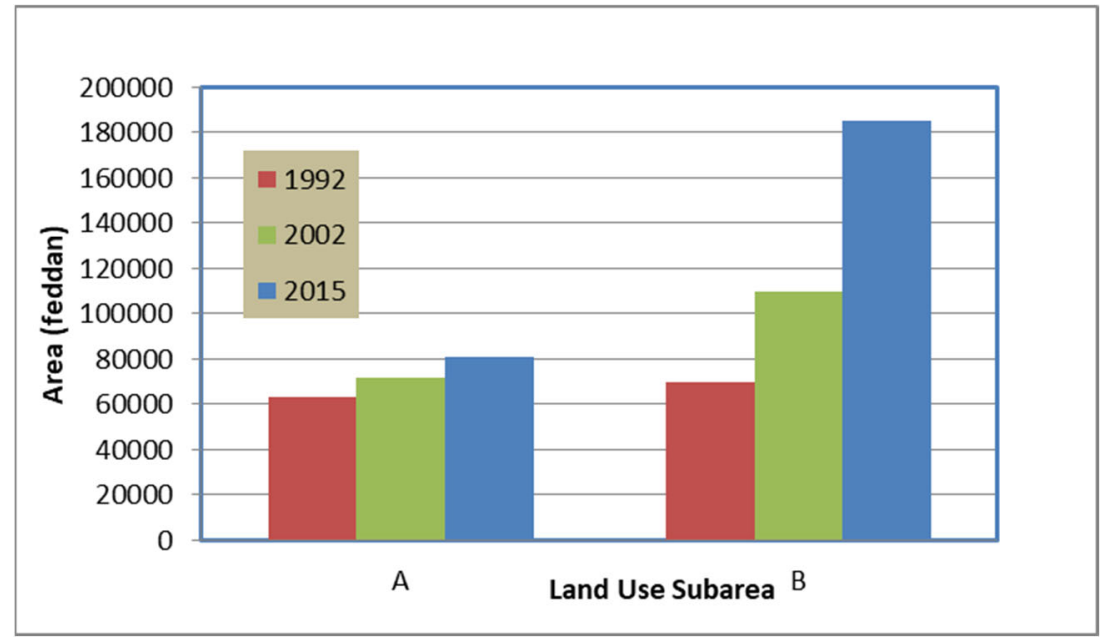

Figure (8) Graphical representation for the amount of Agricultural area increased for land use subarea (A, B) during the period 1992-2015.

\section{7- Conclusions}

It can be concluded from the research that the integration of GIS and remote sensing data as (RS\&GIS) were considered important and powerful tools for accurately detection land use/land cover changes over large areas. The study used three satellite images for years 1992, 2002, 2015 to produce the land use maps by using the maximum likelihood classification processes including a signature file for the Eastern Nile delta region. The signature file was performed by selecting four classes according to the different land cover types existing in the study area. The selected classes of land cover were as (Agricultural, water, desert, and urban).the accuracy of the classification was performed. The results of the accuracy assessment were evaluated as $85 \%, 86.2 \%$, and $87.5 \%$ for the years 1992, 2002, and 2015. Based on the results of the classification process, the change detection between three land use maps was performed and three change detection maps were produced for the study area between (1992-2002), (2002-2015) and (1992-2015). Detailed analysis for the results of change detection was achieved at the high land area located at the desert fringes. The area is divided into two sub-regions (A and B) representing the agricultural development areas that were planned for reclamation by the national water plans. The results showed remarkable active reclamation processes from year 1992 to 2015 especially for the development areas of the Land master plan included in sub-region (B). The reclamation areas which started before 1992 as the 
development areas included in sub-region (A) increased by 175,27.6 feddan from year 1992 to 2015 compared to 115,436 feddan for the development areas of Land master plan included in sub-region (B) for the same period. The results of the research provided the study area with an acceptable and quantitative estimate for the development areas existing at the high land of the Eastern Nile delta desert fringes. This estimation can be useful for planning for sustainable plans for water resource management and future water projects.

\section{References}

Abdel Salam M., Fekry A., Gaame O., and Hussein M., (2004). Groundwater development strategies for drought (case study on the Nile Delta aquifer system) Proc. 3rd. International Symposium on Geophysics, Tanta (2004): 233-243.

Abdulaziz, A. M. (2007). Applications of remote sensing, GIS, and groundwater flow modeling in evaluating groundwater resources; two case studies: East Nile Delta, Egypt and Gold Valley, California, USA. [Ph.D. thesis]: University of Texas at El Paso, $315 \mathrm{p}$.

Abdulaziz, A. M., Hurtado, J, J. M., \& Al-Douri, R. (2009). Application of multitemporal Landsat data to monitor land cover changes in the Eastern Nile Delta region, Egypt. International Journal of Remote Sensing, 30(11), 2977-2996.

Abo EL Magd,M. (2011). the environmental impact assessment $\mathrm{f}$ urbanization in the eastern Nile delta fringes on groundwater system (case study tenth of Ramadan city) phd thesis, faculty of engineering minufiya university

Abu Zeid, M. (1991). Water resources assessment for Egypt. Planning for groundwater development in arid and semi-arid regions, RIGW / IWACO Round Table Meeting, 91:15-34.

Abburu, S., \& Golla, S. B. (2015). Satellite image classification methods and techniques: A review. International journal of computer applications, 119(8).

Ammeish, E. S., Mabrouk, B. M., \& Morsy, W. S. (2016). RS and GIS Based Approach for Detecting Landuse Changes and its Impact on the Groundwater Aquifer. Life Science Journal, 13(4).

ArcGIS, E. S. R. I. (2014). 10.3 Desktop Help. ESRI, Redlands, CA. ArcGIS, 10.

Ban, Y., \& Yousif, O. (2016). Change detection techniques: a review. In Multitemporal Remote Sensing (pp. 1943). Springer, Cham.

Berberoglu, S., \& Akin, A. (2009). Assessing different remote sensing techniques to detect land use/cover changes in the eastern Mediterranean. International Journal of Applied Earth Observation and Geoinformation, 11(1), 46-53.

Bolstad, P., \& Lillesand, T. M. (1991). Rapid maximum likelihood classification. Photogrammetric Engineering and Remote Sensing, 57(1), 67-74.

Borana, S. L., \& Yadav, S. K. (2017). Accuracy Assessment of Land Cover Classification in Jodhpur City Using Remote Sensing and GIS. Int. J. Adv. Res. Comput. Commun. Eng, 6(10), 220-224.

Brown, P., El Gohary, F., Tawfic, M. A., Hamdy, E. I., \& Abdel-Gawad, S. (2003). Nile river water quality management study. Egypt Water Policy Reform, United States Agency for International Development, Egypt.

Elewa, H. H. (2010). Potentialities of water resources pollution of the Nile River Delta, Egypt. The Open hydrology journal, 4(1).

El-Kawy, O. A., Rød, J. K., Ismail, H. A., \& Suliman, A. S. (2011). Land use and land cover change detection in the western Nile delta of Egypt using remote sensing data. Applied geography, 31(2), 483-494.

Esam, I., Abdalla, F., \& Erich, N. (2012). Land use and land cover changes of west tahta region, sohag governorate, upper egypt.

Hegazy, I. R., \& Kaloop, M. R. (2015). Monitoring urban growth and land use change detection with GIS and remote sensing techniques in Daqahlia governorate Egypt. International Journal of Sustainable Built Environment, 4(1), 117-124.

Hussain, M., Chen, D., Cheng, A., Wei, H., \& Stanley, D. (2013). Change detection from remotely sensed images: From pixel-based to object-based approaches. ISPRS Journal of photogrammetry and remote sensing, 80, 91106.

MWRI. (2005).National Water Resources Plan for Egypt 2017,Ministry of Water Resources and Irrigation

Olofsson, P., Foody, G. M., Herold, M., Stehman, S. V., Woodcock, C. E., \& Wulder, M. A. (2014). Good practices for estimating area and assessing accuracy of land change. Remote Sensing of Environment, 148, $42-57$.

Riad, P., Graefe, S., Hussein, H., \& Buerkert, A. (2020). Landscape transformation processes in two large and two small cities in Egypt and Jordan over the last five decades using remote sensing data. Landscape and Urban Planning, 197, 103766.

RIGW/IWACO, (1988). Development and Management of Groundwater Resources in the Nile Valley and Delta, TN70.120-88-07, Research Institute for Groundwater, Kanater EL Khairia, Cairo Egypt .

Singh, A., Kumar, A., \& Upadhyay, P. (2020). Modified possibilistic c-means with constraints (MPCM-S) approach for incorporating the local information in a remote sensing image classification. Remote Sensing Applications: Society and Environment, 100319. 
Zaidi, S. M., Akbari, A., Abu Samah, A., Kong, N. S., Gisen, A., \& Isabella, J. (2017). Landsat-5 Time Series Analysis for Land Use/Land Cover Change Detection Using NDVI and Semi-Supervised Classification Techniques. Polish Journal of Environmental Studies, 26(6).

\section{First Author}

Enass A. Elimy born in Egypt in 1982, Assistant Researcher at Research Institute for Groundwater of National Water Research, obtained her B.Sc. in Civil Engineering (EL Zagazige University, Egypt, 2004), M.Sc. in Irrigation and Hydraulics (Ain shams University, Egypt, 2014).

\section{Second Author}

Ahmed A. Hassan studied Civil Engineering at Ain Shams University from 1975 to 1980. He was awarded his Master of Science in Ain Shams University in 1984. He conducted his Ph.D. research work in Technical University Braunschweig in Germany from 1986 to 1988 and his promotion was in Ain Shams University in 1989. The topic of his Ph.D. research work was "Groundwater Quantity and Quality Modeling". He developed a 2-D finite element model for simulating groundwater flow and contaminant transport in porous media. Hassan worked as a demonstrator from 1980 to 1984, assistant lecturer from 1984 to 1988, lecturer from 1989 to 1995 and assistant professor from 1995 to 2001 in the Irrigation and Hydraulics Department of the Faculty of Engineering, Ain Shams University. Hassan has been working as Professor of Environmental Hydrology in Ain Shams University since 2001. The published research articles are more than 60 in the fields of Irrigation, Hydraulics and Hydrology and supervised many of the M.Sc. and Ph.D. candidates in all Egyptian Universities. Prof. Hassan works as a consultant in the fields of Water Engineering and Hydrology.

\section{Third Author}

Maha Abdel Salam studied Civil Engineering at Ain Shams University from 1973 to 1979. She was awarded her Master of Science in Cairo University in 1984. She conducted her Ph.D. research work Fort Collins, Colorado, U.S.A (part time), and partly in Cairo 1991 to 1994 and her promotion was in Cairo University in 1994. The topic of her Ph.D. research work was "Enhanced Resolution In Finite Element Numerical Simulation of A Well Field ". She developed a computer program that provides an accurate and enhancement local and regional results together through mutual linking between them with efficient use CPU time and memory. Maha has been worked in Research Institute for Groundwater, since 1979. She works in Groundwater Modeling management and development, Water Quality Studies, Development Of Groundwater Potential Maps. She supervised specialized local problem Department. The published research articles are more than 50 in the fields of groundwater development and management, developing potentiality maps for Delta, Hydrologeolical environmental problems, EIA and supervised many of the M.Sc. and Ph.D. candidates in all Egyptian Universities. Prof. Maha works as a consultant in the fields of different committees for water security, irrigation improvement and aquifer sustainability. Fourth Author

Gamal Abdel - Nasser studied soil science at Cairo University .he conducted his Master and Ph.D. at Cairo University. He became Professor.Assistant at 1997 and Professor. at 2003.He shared in many projects related to water. He supervised many of the M.Sc. and Ph.D. candidates in some Egyptian University.

Fifth Author

Dr. Peter Riad is Associate Professor at Irrigation and Hydraulics Department, Faculty of Engineering-Ain Shams University in Cairo-Egypt. He got his MSc. from IHE-Delft/Holland in 2008 and finished his PhD at University of Hannover, Germany in 2012. He has many publications in water structures, groundwater hydrology, water management using GIS and Remote Sensing. He is a member in German-Egyptian Water Cluster and many other water organizations. 